\title{
Farmer's Willingness to Pay for Better Agricultural Information - A Tobit Regression Approach
}

\author{
N.S. Nagesh ${ }^{1 *}$, Amrutha T. Joshi ${ }^{1}$, G.M. Hiremath ${ }^{1}$, G.B. Lokesh ${ }^{1}$, \\ D.M. Chandargi ${ }^{2}$, Jagruti B. Deshmanya ${ }^{1}$ and N. Ananda ${ }^{3}$ \\ ${ }^{1}$ Department of Agricultural Economics, College of Agriculture, UAS, Raichur, India \\ ${ }^{2}$ Department of Agricultural Extension Education, College of Agriculture, UAS, \\ Raichur, India \\ ${ }^{3}$ Department of Agronomy, College of Agriculture, UAS, Raichur, India
}

*Corresponding author

\section{Keywords \\ Willingness to pay, Weather information, Plant protection information, Market information}

\section{Article Info}

Accepted:

15 July 2019 Available Online:

10 August 2019

\section{A B S T R A C T}

Agriculture is said to be a gamble with the vagaries of Monsoon. Most of the farmers face a lot of risky and uncertain situation in which they have to make decisions. Traditionally agricultural information is provided by state development departments, ICAR institutions, commodity boards and NGOs. The recent trend is private extension for high value crops. Farmer needs authentic information to make agriculture a viable and profitable venture. In this context, a study was planned to know the willingness of farmers to pay for better agricultural information. The study covered three districts that are Raichur, Gulbarga and Koppal districts consisting of one irrigated and one rainfed taluk each. Data were gathered from two villages in each taluk making a total sample size of 180 respondents. The results revealed that 72.22 per cent of the respondents in irrigated and 70.00 per cent in rainfed taluks were satisfied with the quantum of information available to them to make decisions. Further assessments were made to know the willingness to pay more money for obtaining additional information and the results revealed that $61.11 \%$ in irrigated region, $51.11 \%$ in rainfed region and $56.11 \%$ in overall were willing to pay more money for additional information. The data on quantum of payment were subjected for tobit regression analysis and the results revealed that farmers were ready to pay Rs 2.94 for composite information which was significant at 1 per cent level, followed by Rs. 1.04 for market information, Rs. 0.66 for weather information and Rs. 1.07 for plant protection information for one unit change in decision making behaviour score. From these results it could be concluded that farmers were willing to pay more for competent information.

\section{Introduction}

Indian economy is mainly an agrarian economy. Though the contribution of Indian agriculture to gross domestic product (GDP) is only around 18 per cent it provides employment to around 50 per cent of the country's workforce. For achieving selfsufficiency in food production, farmers play an important role as stakeholder in our country. Hence, farmers role is imperative to increase food production and that could be seen in terms of influencing farmers to accept and adopt new technology to increase their farm income, modernizing the farm through improved farm machinery, developing the farm with irrigation facilities, strengthening post-harvest operations, timely marketing of 
produce to fetch attractive prices and encouraging savings for investment on farm development, education of children etc.,

A person's willingness to pay is clearly limited by his or her ability to pay. This is appropriate because the method is attempting to elicit what the person would be prepared to forego from current (and future) consumption to achieve an expected improvement in agriculture production (O'brien and Viramontes, 1994). Willingness to pay refers to maximum price a consumer accepts to pay for a given quantity of goods or services

Analysis of determinants of the willingness to pay from logit model showed a significant positive relationship between willingness to pay and household income and farm size. Other household characteristics such as age of household head, media exposure and family size were found to be negative but significantly related to willingness to pay (Temesgen and Tola, 2015).

The study by Mabe et al., (2014) found out that farmers on the average were willing to pay an amount of $\mathrm{GH} \phi 41.20$ annually for weather forecast information. The study also revealed that age, sex, farm size and on-farm income affect the amount farmers were willing to pay for weather forecast information significantly and positively. Weather forecast information delivery should thus be a key factor in all agriculture policy discussions in enhancing farm risk management.

\section{Materials and Methods}

The study was carried out in the Hyderabad Karnataka region. Raichur, Gulbarga and Koppal districts were randomly selected to represent the Hyderabad-Karnataka region. From each district, two taluks were selected, such that one of them represented the rainfed region and the other represented the irrigated region, based on the net irrigated area. From each of the selected taluks, two Gram panchayats were selected randomly, and from each panchayat a village was selected randomly. Thus, totally 12 villages were selected for the study. From each selected village fifteen farmers were selected using simple random sampling method. Thus, the total sample size constituted of 180 respondents.

Willingeness to pay for better agricultural information by the respondents was elicited through 'bidding game' approach. The bidding game method of contingent valuation is one way to increase the precision of willingness to pay estimates relative to other methods such as the single dichotomous choice approach. Bidding game provides 'thinking time' to elicit maximum willingeness to pay as desired. In a bidding format respondents were exposed to a starting bid and further bidding depending upon their response (yes / no). Bidding game begins with an interviewer postulating an initial bid to a respondent. Further bidding depends upon their response 'yes' or 'no'.

If the respondent was willing to pay the initial bid, the interviewer revises the bid upward until a negative response was obtained. A negative response to the initial bid results in the interviewer revising the bid downward until an acceptable amount was found. The final measure of the respondents Hicksian compensating or equivalent surplus for the item being valued (Boyle et al., 1985). Further the determinants of the willingness to pay were estimated by using the following tobit model:

$\mathrm{WTP}=\theta_{0}+\sum_{i=1}^{n=8} \theta_{\mathrm{i}} \mathrm{X}_{\mathrm{i}}+\sum_{i=1}^{n=2} \alpha_{\mathrm{j}} \mathrm{D}_{\mathrm{i}}+\mathrm{u}_{\mathrm{i}}$

Where,

$\mathrm{WTP}=$ Willingness to pay for better agricultural information 
$\theta_{\mathrm{i}}(\mathrm{i}=0 \ldots . .8)=$ Parameters to be estimated

$\alpha_{\mathrm{j}}(\mathrm{j}=0 \ldots 2)=$ Parameters to be estimated

$\mathrm{D}_{1}=$ Irrigated Rainfed Dummy ( 1 = Irrigated land, otherwise Rainfed land)

$\mathrm{X}_{1}=$ Age (years)

$\mathrm{X}_{2}=$ No. of years of schooling (years)

$\mathrm{X}_{3}=$ No. of family Members (No.)

$\mathrm{D}_{2}=$ Family type Dummy $(1=$ Joint, otherwise nuclear family)

$\mathrm{X}_{4}=$ Achievement Motivation Score

$\mathrm{X}_{5}=$ Risk orientation Score

$\mathrm{X}_{6}=$ Economic Motivation Score

$\mathrm{X}_{7}=$ Mass media participation Score

$\mathrm{X}_{8}=$ Decision Making Behaviour Score

\section{Results and Discussion}

Satisfaction with the quantum of information available to make decisions was studied and presented in Table 1. Under irrigated condition, 72.22 per cent were satisfied with the information available to make decisions. The rest 27.78 per cent were not satisfied with the quantum of information available to make decisions. In rainfed situation, 70.00 per cent of the respondents were satisfied with the information available, while the rest 30.00 per cent were not satisfied with the quantum of information available to make decisions. It was observed that the percentage of farmers who expressed satisfaction with the quantum of information available to make decisions was happened to be almost the same both in irrigated and rainfed situation. In the overall situation, 71.11 per cent of the respondents were satisfied with the quantum of information available and 28.89 per cent were not satisfied with the quantum of information available to make decisions. Farmers satisfied with the quantum of information obtained to make decisions were more than those not satisfied with the quantum of information to make decisions.

Willingness to pay money for obtaining better agricultural information was studied to draw some insights for cost of decision making. Under irrigated condition it was noted that 61.11 per cent of the respondents were willing to pay money for obtaining additional agricultural information. As much as 38.89 per cent of the respondents were not willing to pay for the additional agricultural information. In rainfed situation, it was observed that 51.11 per cent of the respondents were willing to pay for the additional agricultural information, while the rest 48.89 per cent were not willing to pay money for the additional agricultural information. The percentage of farmers willing to pay money for obtaining additional information were more in irrigated situation than the rainfed situation. This may be attributed to more assured income in irrigated situation compared to rainfed situation. In the overall situation 56.11 per cent of respondents were willing to pay for additional agricultural information and the rest 43.89 per cent were not willing to pay for additional agricultural information. In the overall situation percentage of farmers willing to pay for additional agricultural information were relatively more than those not willing to pay for additional agricultural information. This implies that farmers need additional agricultural information for achieving success in their agripreneurship.

A detailed analysis of willingness to pay for specific agricultural information was done and presented in Table 2. Among the irrigated group of farmers, 23.33 per cent of the farmers 
had agreed to pay for weather information to an extent of $\square 15.98$ per acre. For plant protection information, 54.44 per cent of the respondents were willing to pay $\square 14.89$ per acre. In case of price information, 37.78 per cent of the respondents were willing to pay $\square 14.80$ per acre. A majority $(61.11 \%)$ of respondents were willing to pay $\square 18.10$ for composite information.

In case of rainfed group of farmers, 31.11 per cent were willing to pay $\square 17.50$ per acre for weather information, 43.33 per cent were willing to pay $\square \quad 15.31$ per acre for plant protection related information, 30.00 per cent were willing to pay $\square 15.88$ per acre for price information and 51.11 per cent were willing to pay $\square 24.81$ per acre for composite information. In the overall group of farmers, 27.22 per cent were willing to pay $\square 17.35$ per acre for weather information, 48.89 per cent were willing to pay $\square 14.88$ per acre for plant protection information, 33.89 per cent were willing to pay $\square 15.13$ per acre for price information and 56.11 per cent were willing to pay $\square 21.22$ per acre for composite information on agriculture.

The percentage of farmers willing to pay for weather information was more in rainfed situation than in irrigated situation. This was because rainfed farmers were more subjected to the vagaries of weather particularly rainfall than irrigated farmers. This could be further emphasised that the operations in the rainfed situation were more dependent on quantum of rainfall and its distribution. In the overall situation only 27.22 per cent of the respondents were willing to pay for weather information. The percentage of farmers willing to pay for plant protection information were more in case of irrigated situation than in rainfed situation. This could be attributed to the fact that in the irrigated situation farmers tend to cultivate crops more intensively leading to luxuriant growth of the crops. This could attract more pest and diseases in irrigated situation than rainfed situation. Further as the irrigated farmers enjoy a definite assured income compared to rainfed farmers their willingness to pay for plant protection information was high. In the overall situation nearly half of the respondents were willing to pay for plant protection information which implies the importance of plant protection in successful harvest of the crop. Willingness to pay for market information was more in case of irrigated situation than in rainfed situation. In irrigated situation farmers tend to spend more on cost of cultivation than rainfed situation and therefore they anticipate more returns by obtaining proper market information. In the overall situation one third of the farmers were willing to pay for market information. The percentage of farmers willing to pay for composite information was more in irrigated situation than in rainfed situation. In the overall situation more than half of the respondents were willing to pay for composite information. It was interesting to note that the rainfed farmers were willing to pay more per unit area compared to irrigated farmers for all categories of information viz. weather, plant protection, market and composite information. Considering this, it could be concluded that the rainfed farmers were in a more risk prone situation than irrigated farmers and therefore they were ready to spend more money for taking appropriate decisions.

Results on factors influencing willingness to pay for better composite information are presented in Table 3. The latent willingness to pay for better composite information was significantly influenced by number of years of schooling, economic motivation score and decision making behaviour score. Whether the individual was an irrigated or rainfed farmer, had no significant influence on the willingness to pay for better composite information. If the individual's decision making behaviour score 
increases by one unit, the latent willingness to pay for better composite information increases by $\square 5.20$. If the individuals economic motivation score increases by one unit, the latent willingness to pay for better composite information increases by $\square$ 25.21. If the individual's education increases by one more unit of schooling, the latent willingness to pay for better composite information increases by $\square$ 5.67. The actual willingness to pay for better composite information was significantly influenced by number of years of schooling, economic motivation score and decision making behaviour score. If the individuals decision making behaviour score increases by one unit, the actual willingness to pay for better composite information increases by $\square$ 2.94. If the individuals economic motivation score increases by one unit, the actual willingness to pay for better composite information increases by $\square 14.25$. If the individuals education increases by one more unit of schooling, the actual willingness to pay for better composite information increases by $\square 3.21$.

The improvement in the decision making behaviour score implies improvement in knowledge, skill and attitude of farmers. This in turn has resulted in higher willingness to pay for better composite information. An increase in the economic motivation increases risk taking ability of farmers and thus enhancing the willingness to pay for better composite information. As the education level increases the people's awareness level increases and they would be willing to pay higher money for the composite information

Results on factors influencing willingness to pay for better market information are presented in Table 4. The latent willingness to pay for better market information is significantly influenced by number of family members and decision making behaviour score. If the individual's decision making behaviour score increases by one unit, the latent willingness to pay for better market information increases by $\square$ 3.08. With each additional member in the family, the latent willingness to pay for better market information decreases by $\square 7.51$.

The actual willingness to pay for better market information was significantly influenced by number of family members and decision making behaviour score. If the individual's decision making behaviour score increases by one unit, the actual willingness to pay for better market information increases by $\square 1.04$. With each additional member in the family, the actual willingness to pay for better market information decreases by $\square 2.53$.

The improvement in the decision making behaviour score implies improvement in knowledge, skill and attitude of farmers. This in turn has resulted in higher willingness to pay for better market information. This result is in line with the fact that with every additional increase in the member of the family, the capacity to pay for the market information decreases.

Results on factors influencing willingness to pay for better plant protection information are presented in Table 5. The latent willingness to pay for better plant protection information was significantly influenced by number of years of schooling, economic motivation score and decision making behaviour score. If the individual's decision making behaviour score increases by one unit, the latent willingness to pay for better plant protection information increases by $\square$ 2.05. If the individuals economic motivation score increases by one unit, the latent willingness to pay for better plant protection information increases by $\square$ 14.16. If the individuals' education increases by one more unit of schooling, the latent willingness to pay for better plant protection information increases by $\square 3.24$. 
Table.1 Willingness to pay for better agricultural information

\begin{tabular}{|c|c|c|c|c|c|c|c|}
\hline \multirow[t]{2}{*}{ Particulars } & \multirow[t]{2}{*}{ Response } & \multicolumn{2}{|c|}{ Irrigated $\left(n_{1}=90\right)$} & \multicolumn{2}{|c|}{ Rainfed $\left(n_{2}=90\right)$} & \multicolumn{2}{|c|}{ Overall $(n=180)$} \\
\hline & & $\begin{array}{l}\text { Number } \\
\text { (No.) }\end{array}$ & $\begin{array}{c}\text { Percent } \\
(\%)\end{array}$ & $\begin{array}{l}\text { Number } \\
\text { (No.) }\end{array}$ & $\begin{array}{l}\text { Percent } \\
(\%)\end{array}$ & $\begin{array}{l}\text { Number } \\
\text { (No.) }\end{array}$ & $\begin{array}{c}\text { Percent } \\
(\%)\end{array}$ \\
\hline \multirow{2}{*}{$\begin{array}{l}\text { Satisfaction with the } \\
\text { Quantum of information } \\
\text { available to make decisions }\end{array}$} & Yes & 65 & 72.22 & 63 & 70.00 & 128 & 71.11 \\
\hline & No & 25 & 27.78 & 27 & 30.00 & 52 & 28.89 \\
\hline \multirow{2}{*}{$\begin{array}{l}\text { Willingness to pay money } \\
\text { for obtaining additional } \\
\text { information }\end{array}$} & Yes & 55 & 61.11 & 46 & 51.11 & 101 & 56.11 \\
\hline & No & 35 & 38.89 & 44 & 48.89 & 79 & 43.89 \\
\hline
\end{tabular}

Table.2 Willingness to pay for different categories of agricultural information

\begin{tabular}{|c|c|c|c|c|c|c|c|c|c|}
\hline \multirow[t]{2}{*}{ Willingness to Pay for } & \multicolumn{3}{|c|}{ Irrigated $\left(\mathrm{n}_{1}=90\right)$} & \multicolumn{3}{|c|}{ Rainfed $\left(n_{2}=90\right)$} & \multicolumn{3}{|c|}{ Overall $(n=180)$} \\
\hline & $\begin{array}{l}\text { Number } \\
\text { (No.) }\end{array}$ & $\begin{array}{l}\text { Percent } \\
(\%)\end{array}$ & $\begin{array}{l}\text { Average } \\
\text { amount } \\
\text { ( } \square / \text { acre) }\end{array}$ & $\begin{array}{l}\text { Number } \\
\text { (No.) }\end{array}$ & $\begin{array}{l}\text { Percent } \\
(\%)\end{array}$ & $\begin{array}{l}\text { Average } \\
\text { amount } \\
(\square / \text { acre })\end{array}$ & $\begin{array}{l}\text { Numbe } \\
\text { r (No.) }\end{array}$ & $\begin{array}{l}\text { Percent } \\
(\%)\end{array}$ & $\begin{array}{l}\text { Average } \\
\text { amount } \\
\text { ( } \square / \text { acre) }\end{array}$ \\
\hline Weather information & 21 & 23.33 & 15.98 & 28 & 31.11 & 17.50 & 49 & 27.22 & 17.35 \\
\hline $\begin{array}{ll}\text { Pest } & \text { Disease } \\
\text { information } & \end{array}$ & 49 & 54.44 & 14.89 & 39 & 43.33 & 15.31 & 88 & 48.89 & 14.88 \\
\hline Price information & 34 & 37.78 & 14.80 & 27 & 30.00 & 15.88 & 61 & 33.89 & 15.13 \\
\hline Composite information & 55 & 61.11 & 18.10 & 46 & 51.11 & 24.81 & 101 & 56.11 & 21.22 \\
\hline
\end{tabular}


Table.3 Willingness to pay for better Composite information

\begin{tabular}{|c|c|c|c|c|}
\hline \multirow[t]{3}{*}{ Independent variable } & \multicolumn{4}{|c|}{$\begin{array}{l}\text { Dependent variable: Willingness to pay for } \\
\text { Composite information }\end{array}$} \\
\hline & \multicolumn{2}{|c|}{ Tobit $\left(\mathrm{Y}^{*}\right)$} & \multicolumn{2}{|c|}{$\begin{array}{l}\text { Tobit marginal effects for } \\
\text { censored sample }(\mathrm{Y})\end{array}$} \\
\hline & $b_{i}$ & $\mathrm{z}$ & $b_{i}$ & $\mathrm{t}$ \\
\hline Intercept & $-288.95 * *$ & -2.55 & & \\
\hline Irrigated Rainfed Dummy (D1) & 20.64 & 0.82 & 11.67 & 0.82 \\
\hline Age (yrs) & 0.20 & 0.24 & 0.11 & 0.24 \\
\hline No. of years of schooling (yrs) & $5.67 * *$ & 1.96 & $3.21 *$ & 1.96 \\
\hline No. of family Members (No.) & 2.44 & 0.48 & 1.38 & 0.48 \\
\hline Family type Dummy (D2) & -37.06 & -1.14 & -20.95 & -1.15 \\
\hline Achievement Motivation Score & 3.78 & 0.84 & 2.14 & 0.84 \\
\hline Risk orientation Score & -1.92 & -0.15 & -1.08 & -0.14 \\
\hline Economic Motivation Score & $25.21 *$ & 1.87 & $14.25^{*}$ & 1.88 \\
\hline Mass media participation Score & -2.25 & -0.61 & -1.27 & -0.61 \\
\hline Decision Making Behaviour Score & $5.20^{* * * *}$ & 4.05 & $2.94 * * *$ & 4.04 \\
\hline Log-likelihood & \multicolumn{4}{|c|}{-686.2 on $12 \mathrm{df}$} \\
\hline Wald-statistic & \multicolumn{4}{|c|}{49.13 on $10 \mathrm{df}$} \\
\hline
\end{tabular}

Note: $* * *=$ Significant at $1 \%$ level

$* *=$ Significant at $5 \%$ level

$*=$ Significant at $10 \%$ level

Table.4 Willingness to pay for better market information

\begin{tabular}{|c|c|c|c|c|}
\hline \multirow[t]{3}{*}{ Independent variable } & \multicolumn{4}{|c|}{$\begin{array}{l}\text { Dependent variable: Willingness to pay for market } \\
\text { information }\end{array}$} \\
\hline & \multicolumn{2}{|l|}{ Tobit $\left(\mathrm{Y}^{*}\right)$} & \multicolumn{2}{|c|}{$\begin{array}{l}\text { Tobit marginal effects for } \\
\text { censored sample }(\mathrm{Y})\end{array}$} \\
\hline & $b_{i}$ & $\mathrm{z}$ & $b_{i}$ & $\mathrm{t}$ \\
\hline Intercept & $-168.08 * *$ & -2.37 & & \\
\hline Irrigated Rainfed Dummy (D1) & 27.42 & 1.76 & 9.24 & 1.79 \\
\hline Age (yrs) & -0.06 & -0.12 & -0.02 & -0.12 \\
\hline No. of years of schooling (yrs) & 1.02 & 0.59 & 0.35 & 0.59 \\
\hline No. of family Members (No.) & $-7.51 * *$ & -2.01 & $-2.53 * *$ & -2.03 \\
\hline Family type Dummy (D2) & 7.90 & 0.40 & 2.66 & 0.40 \\
\hline Achievement Motivation Score & 3.61 & 1.31 & 1.22 & 1.31 \\
\hline Risk orientation Score & -1.68 & -0.21 & -0.57 & -0.20 \\
\hline Economic Motivation Score & 10.65 & 1.31 & 3.59 & 1.32 \\
\hline Mass media participation Score & -0.89 & -0.41 & -0.30 & -0.41 \\
\hline Decision Making Behaviour Score & $3.08 * * *$ & 4.07 & $1.04 * * *$ & 4.05 \\
\hline Log-likelihood & \multicolumn{4}{|c|}{-400.4 on $12 \mathrm{df}$} \\
\hline Wald-statistic & \multicolumn{4}{|c|}{37.42 on $10 \mathrm{df}$} \\
\hline
\end{tabular}

Note: $* * *=$ Significant at $1 \%$ level

$* *=$ Significant at $5 \%$ level 
Table.5 Willingness to pay for better plant protection information

\begin{tabular}{|c|c|c|c|c|}
\hline \multirow[t]{3}{*}{ Independent variable } & \multicolumn{4}{|c|}{$\begin{array}{l}\text { Dependent variable: Willingness to pay for } \\
\text { plant protection information }\end{array}$} \\
\hline & \multicolumn{2}{|c|}{ Tobit $\left(\mathrm{Y}^{*}\right)$} & \multicolumn{2}{|c|}{$\begin{array}{l}\text { Tobit marginal effects } \\
\text { for censored sample }(Y)\end{array}$} \\
\hline & $b_{i}$ & $\mathrm{z}$ & $\mathrm{b}_{\mathrm{i}}$ & $\mathrm{t}$ \\
\hline Intercept & $-165.66 * * *$ & -3.06 & & \\
\hline Irrigated Rainfed Dummy (D1) & 15.77 & 1.33 & 8.21 & 1.34 \\
\hline Age (yrs) & 0.44 & 1.12 & 0.23 & 1.13 \\
\hline No. of years of schooling (yrs) & $3.24 * *$ & 2.37 & $1.69 * *$ & 2.38 \\
\hline No. of family Members (No.) & 1.10 & 0.46 & 0.57 & 0.46 \\
\hline Family type Dummy (D2) & -8.34 & -0.55 & -4.34 & -0.55 \\
\hline Achievement Motivation Score & 1.96 & 0.94 & 1.02 & 0.94 \\
\hline Risk orientation Score & -5.18 & -0.85 & -2.70 & -0.85 \\
\hline Economic Motivation Score & $14.16 * *$ & 2.22 & $7.37 * *$ & 2.24 \\
\hline Mass media participation Score & -0.22 & -0.13 & -0.11 & -0.13 \\
\hline Decision Making Behaviour Score & $2.05 * * *$ & 3.47 & $1.07 * * *$ & 3.47 \\
\hline Log-likelihood & \multicolumn{4}{|c|}{-539.6 on $12 \mathrm{df}$} \\
\hline Wald-statistic & \multicolumn{4}{|c|}{45.9 on $10 \mathrm{df}$} \\
\hline
\end{tabular}

Note: $* * *=$ Significant at $1 \%$ level

$* *=$ Significant at $5 \%$ level

Table.6 Willingness to pay for better weather information

\begin{tabular}{|c|c|c|c|c|}
\hline \multirow[t]{3}{*}{ Independent variable } & \multicolumn{4}{|c|}{$\begin{array}{l}\text { Dependent variable: Willingness to pay for } \\
\text { Weather information }\end{array}$} \\
\hline & \multicolumn{2}{|c|}{ Tobit $\left(\mathrm{Y}^{*}\right)$} & \multicolumn{2}{|c|}{$\begin{array}{l}\text { Tobit marginal effects for } \\
\text { censored sample }(\mathrm{Y})\end{array}$} \\
\hline & $\mathrm{b}_{\mathrm{i}}$ & $\mathrm{z}$ & $b_{i}$ & $\mathrm{t}$ \\
\hline Intercept & $-190.84 * *$ & -2.04 & & \\
\hline Irrigated Rainfed Dummy (D1) & -17.28 & -0.86 & -4.37 & -0.85 \\
\hline Age (yrs) & -0.55 & -0.82 & -0.14 & -0.82 \\
\hline No. of years of schooling (yrs) & 2.88 & 1.30 & 0.73 & 1.29 \\
\hline No. of family Members (No.) & $7.91 * *$ & 2.01 & $2.00 * *$ & 2.03 \\
\hline Family type Dummy (D2) & $-66.69 * *$ & -2.42 & $-16.88 * *$ & -2.47 \\
\hline Achievement Motivation Score & 0.89 & 0.23 & 0.22 & 0.23 \\
\hline Risk orientation Score & 13.06 & 1.12 & 3.30 & 1.13 \\
\hline Economic Motivation Score & 11.74 & 1.05 & 2.97 & 1.06 \\
\hline Mass media participation Score & -4.43 & -1.47 & -1.12 & -1.47 \\
\hline Decision Making Behaviour Score & $2.59 * *$ & 2.55 & $0.66 * *$ & 2.57 \\
\hline Log-likelihood & \multicolumn{4}{|c|}{-340.9162 on $12 \mathrm{df}$} \\
\hline Wald-statistic & \multicolumn{4}{|c|}{26.55 on $10 \mathrm{df}$} \\
\hline
\end{tabular}

Note: $* *=$ Significant at $5 \%$ level 
The actual willingness to pay for better plant protection information was significantly influenced by number of years of schooling, economic motivation score and decision making behaviour score. If the individual's decision making behaviour score increases by one unit, the actual willingness to pay for better plant protection information increases by $\square 1.07$. If the individuals economic motivation score increases by one unit, the actual willingness to pay for better plant protection information increases by $\square 7.37$. If the individual's education increases by one more unit of schooling, the actual willingness to pay for better plant protection information increases by $\square 1.69$.

The improvement in the decision making behaviour score implies improvement in knowledge, skill and attitude of farmers. This in turn has resulted in higher willingness to pay for better plant protection information. An increase in the economic motivation increases risk taking ability of farmers and thus enhancing the willingness to pay for better plant protection information.

As the education level increases the people's awareness level increases and they would be willing to pay higher money for the plant protection information.

Results on factors influencing willingness to pay for better weather information are presented in Table 6 . The latent willingness to pay for better weather information was significantly influenced by number of family members, family type dummy and decision making behaviour score. If the individual's decision making behaviour score increases by one unit, the latent willingness to pay for better weather information increases by $\square$ 2.59. With each additional member in the family, the latent willingness to pay for better weather information increases by $\square$ 7.91. The latent willingness to pay for better weather information was $\square 66.69$ lower for a joint household in comparison to a nuclear household. The actual willingness to pay for better weather information was significantly influenced by number of family members, family type dummy and decision making behaviour score. If the individual's decision making behaviour score increases by one unit, the actual willingness to pay for better weather information increases by $\square 0.66$. With each additional member in the family, the actual willingness to pay for better weather information increases by $\square 7.91$. The actual willingness to pay for better weather information was $\square 16.88$ lower for a joint household in comparison to a nuclear household.

The improvement in the decision making behaviour score implies improvement in knowledge, skill and attitude of farmers. This in turn has resulted in higher willingness to pay for better weather information. With every additional member in the family, the willingness to pay for better weather information increases. As weather plays a predominant role in successful agriculture they were willing to pay more for better weather information even in case of additional members in the family. The joint family household was willing to pay lower money for better weather information in comparison to a nuclear family household.

From the results and discussion it could be concluded that for one unit change in decision making behaviour score, farmers were ready to pay $\square 2.94$ for composite information, followed by $\square 1.04$ for market information, $\square 0.66$ for weather information and $\square 1.07$ for plant protection information. Further, the rainfed farmers were willing to pay more per unit area compared to irrigated farmers for all categories of information viz. weather, plant protection, market and composite information. 


\section{References}

Boyle K. J., Richard, C. B. and Michael, P. W., 1985. Starting point bias in contingent evaluation bidding games. Land Economics, 61(2): 188-194.

Mabe, F. N., Nketiah, P., Darko, D., 2014. Farmers' willingness to pay for weather forecast information in SaveluguNanton municipality of the Northern region, Russian Journal of Agricultural and Socio-Economic Sciences, 12(36): 34-44.
O'Brien, B. and Viramontes, J. L., 1994. Willingness to Pay: A Valid and Reliable Measure of Health State Preference? Med Decis Making, 14: 289-297.

Temesgen, D. and Tola, T., 2015. Determinates of small holder farmers willingness to pay for agricultural extension services: A case study from Eastern Ethiopia, African Journal of Agricultural Research, 10(20): 21522158.

\section{How to cite this article:}

Nagesh, N.S., Amrutha T. Joshi, G.M. Hiremath, G.B. Lokesh, D.M. Chandargi, Jagruti B. Deshmanya and Ananda, N. 2019. Farmer's Willingness to Pay for Better Agricultural Information - A Tobit Regression Approach. Int.J.Curr.Microbiol.App.Sci. 8(08): 1872-1881. doi: https://doi.org/10.20546/ijcmas.2019.808.220 